\title{
Melatonin has a stimulatory effect on osteoblasts by upregulating COL-I and OPN expression/secretion
}

\author{
Karen Dalla-Costa, Fikriye V. Yurtsever, Julia Penteado, Elizabeth F. Martinez, Marcelo \\ Sperandio, Daiane C. Peruzzo.
}

Faculdade de Odontologia São Leopoldo Mandic, Departamento de Pesquisa em Odontologia, Campinas, São Paulo, Brasil.

\begin{abstract}
Melatonin (MLT) is a potential signaling molecule in the homeostasis of bone metabolism and may be an important mediator of bone formation and stimulation. The aim of this in vitro study was to evaluate the effect of MLT on the viability, $m R N A$ /protein expression and mineralization of pre-osteoblastic cells. The concentrations 5, 2.5, 1, 0.1 and 0.01 mM MLT were tested on pre-osteoblastic cells (MC3T3) compared to control (no MLT), evaluating proliferation and cell viability (C50), gene expression (RT-PCR) and secretion (ELISA) of COL-I and $O P N$ at $24 \mathrm{~h}, 48 \mathrm{~h}$ and $72 \mathrm{~h}$, and the formation of mineral nodules (alizarin red and fast red) after 10 days of treatment. MLT at 5 and $2.5 \mathrm{mM}$ proved to be cytotoxic (C50), so only 0.01, 0.1 and $1 \mathrm{mM}$ were used for the subsequent analyses. OPN $\mathrm{mRNA}$
\end{abstract}

expression increased with MLT at $0.1 \mathrm{mM}-1 \mathrm{mM}$, which was followed by increased secretion of OPN both at $24 \mathrm{~h}$ and $72 \mathrm{~h}$ compared to the remaining groups $(p<0.05)$. COL-I $m R N A$ and COL-1 secretion followed the same pattern as OPN at $0.1 \mathrm{mM}$ $M L T$ at $72 \mathrm{~h}$ of treatment $(p<0.05)$. Regarding mineralization, all MLT doses (except $1 \mathrm{mM}$ ) caused an increase $(p<0.05)$ in the formation of mineral nodules compared to the control. Melatonin at $0.01 \mathrm{mM}-1 \mathrm{mM}$ had a stimulatory effect on osteoblasts by upregulating COL-I and OPN expression/ secretion and mineralization, thereby fostering osteogenesis. Received: March 2020; Accepted July 2020.

Keywords: collagen- melatonin- osteogenesis- osteopontin.

\section{Melatonina tem efeito estimulador em osteoblastos, pela regulação positiva da expressão/secreção de COL-I e OPN}

\begin{abstract}
RESUMO
A melatonina (MLT) é uma molécula potencial de sinalização na homeostase do metabolismo ósseo e pode ser um importante mediador da formação e estimulação óssea. O objetivo deste estudo in vitro foi avaliar o efeito da MLT na viabilidade, na expressão do mRNA da proteína e mineralização de células préosteoblásticas. As concentrações de MLT 5, 2,5, 1, 0,1 e 0,01 mM foram testadas em células pré-osteoblásticas da linhagem MC3T3 em comparação ao controle (sem MLT), avaliando a proliferação e a viabilidade celular (C50), expressão gênica (rtPCR) e secreção (Elisa) de Colágeno tipo 1 (COL-I) e osteopontina (OPN) às 24, 48 e 72 horas, além da formação de nódulos minerais por meio do teste vermelho de Alizarina fast red após 10 dias de tratamento. MLT a 5 e 2,5 mM provou ser tóxico (C50). Portanto, as concentrações de 0,01, 0,1 e $1 \mathrm{mM}$
\end{abstract}

\section{INTRODUCTION}

Melatonin (MLT) is the main hormone synthesized and secreted by the pineal gland. Its functions include regulating various physiological processes foram utilizadas para as análises subsequentes. A expressão do mRNA da OPN aumentou com MLT a 0,1 mM-1mM, seguida pela secreção aumentada de OPN às 24 e 72 horas em comparação aos demais grupos ( $p<0,05)$. O mRNA de COL-I e a secreção de COL-I seguiram o mesmo padrão do OPN a 0,1 $m M$ de MLT em 72 horas de tratamento $(p<0,05)$. Em relação à mineralização, todas as doses de MLT (exceto $1 \mathrm{mM}$ ) causaram aumento $(p<0,05)$ na formação de nódulos minerais em comparação ao controle. A MLT na concentração entre $0,01 \mathrm{mM}$ a $1 \mathrm{mM}$ teve um efeito estimulador sobre os osteoblastos, ao regular positivamente a expressão e secreção de COL-I e OPN, além da mineralização, favorecendo a osteogênese.

Palavras-chave: colágeno- melatonina- osteogêneseosteopontina.

in different parts of the body, such as circadian rhythm ${ }^{1}$, body temperature ${ }^{2}$, immune system ${ }^{3}$, sexual development ${ }^{4}$ and reproductive cycle ${ }^{5}$. MLT levels in the body are related to ambient light, reaching 
maximum levels at night when it is dark and lowest levels throughout the duration of daylight ${ }^{6}$.

MLT may be administered in several ways such as orally and intraperitoneally as a supplement or prescription-only, depending on the country. It is inexpensive and has few side effects compared to other drugs and can be used with a wide safety margin. Such features combined with the series of reported effects on different tissues make melatonin a potent therapeutic option for several ailments and/ or prevention thereof'.

Studies have demonstrated the influence of MLT in cell differentiation by stimulation or suppression, depending on dose and cell type ${ }^{8,9}$. MLT is believed to have the potential to play a key role in regulating bone growth since at therapeutic doses it may inhibit osteoclastic activity and induce osteoblast differentiation ${ }^{10}$.

A previous study revealed that MLT enhances mesenchymal stem cell differentiation into mature osteoblasts through the MT2 receptor ${ }^{11}$ and during osteoblastic differentiation, MLT increases the expression of osteocalcin (OC), a highly specific marker of bone formation, followed by enhanced bone mineralization ${ }^{12}$. It has also been demonstrated that MLT has the ability to stimulate the proliferation and synthesis of type I collagen, as well as other bone matrix proteins and bone markers (alkaline phosphatase, osteopontin and osteocalcin) at micromolar concentrations in human osteoblasts in vitro ${ }^{9}$, though the mechanisms by which such phenomena take place remain largely ill-understood. The oral cavity is affected by a number of conditions such as periodontitis, mucositis, neoplasms and cytotoxicity from various drugs and/ or biomaterials. MLT has been shown to downregulate the expression of pro-inflammatory factors such as C- reactive protein, interleukin- 6 and tumor necrosis factor-alpha ${ }^{2}$ as well as receptor activators of nuclear factor kappa-B ligand/osteoprotegerin ratios to reduce periodontal inflammation ${ }^{2,13,23,24}$. In addition to up-regulating salivary acid phosphatase, alkaline phosphatase, osteopontin, and osteocalcin, MLT has been associated to positive outcomes regarding gingival index and pocket probing depth, which are highly suggestive of enhanced osteoblast differentiation and bone formation ${ }^{14,17,23,24}$.

Despite the numerous current and potential applications of MLT, further studies are needed to ascertain the effect of melatonin on bone cells to serve as the basis for in vivo studies and ultimately safe long-term clinical use. Therefore, the aim of the present study was to evaluate in vitro the effect of the hormone melatonin on the proliferation, viability, bone matrix protein expression and mineralization capacity of pre-osteoblastic cells.

\section{MATERIALS AND METHODS}

\section{Experimental design}

This was an analytical bifactorial experimental study, in which the following doses of melatonin were tested: $0.01 \mathrm{mM}(\mathrm{C} 1), 0.1 \mathrm{mM}(\mathrm{C} 2), 1 \mathrm{mM}(\mathrm{c} 3), 2.5 \mathrm{mM}(\mathrm{C} 4)$ and $5 \mathrm{mM}(\mathrm{C} 5)$ and a control group (C6) at 24h, $48 \mathrm{~h}$, $72 \mathrm{~h}$ and 10 days after treatment.

MLT powder $\geq 98 \%$ (N-acetyl-5-methoxytryptamine) and M5250 Sigma (Sigma, St. Louis, Missouri, USA), reconstituted in $50 \mathrm{mg} / \mathrm{mL}$ absolute ethanol were used. The control group received the highest dose of ethanol (vehicle), but no MLT.

\section{Cell culture}

A mouse-derived pre-osteoblastic cell line (MC3T3-E1) obtained from the ATCC (American Type Culture Collection, ATCC, VC, USA) was used, supplemented with $15 \%$ fetal bovine serum (Nutricell Cellular Nutrients, Campinas, SP, Brazil), $100 \mathrm{IU} / \mathrm{ml}$ penicillin (Sigma) and $50 \mathrm{mg} / \mathrm{ml}$ streptomycin (Sigma).

For the mineralization assays, the cultures were supplemented with $50 \mu \mathrm{g} / \mathrm{mL}$ ascorbic acid, $100 \mu \mathrm{g} /$ $\mathrm{mL}$ beta-glycerophosphate (Sigma, St. Louis, MO, USA), $95 \% \mathrm{O}_{2}$ and $5 \% \mathrm{CO}_{2}$.

At $70 \%$ sub-confluence, the culture medium was removed and $0.25 \%$ trypsin (Nutricell Nutrientes Celulares) and 1mM EDTA (Gibco) solution were added to gather the cells in suspension. Then the cells were seeded - 3.5x103 cells / well in 96-well polystyrene plates (Sarstedt). After 24 hours, the medium was changed and the osteoblastic cells treated with MLT at 0.01, 0.1, 1, 2.5 and $5 \mathrm{mM}$.

\section{Cell proliferation assay}

The Trypan blue vital exclusion method was used at $24 \mathrm{~h}, 48 \mathrm{~h}$ and $72 \mathrm{~h}$ of treatment with MLT at 0.01, $0.1,1,2.5$ and $5 \mathrm{mM}$.

\section{Cell viability assay (MTT)}

Cell cultures were tested for cell viability using the MTT assay. After solubilization of the crystals, 
quantification was performed on an ELX800 microplate reader (Biotek Instruments, Inc.) at $590 \mathrm{~nm}$. The cytotoxic dose (C50) was then determined based on the MTT assay findings. This represents cell viability below $50 \%$ in relation to the control group.

\section{mRNA expression for collagen type I (COL-I) and osteopontin (OPN)}

Real-time polymerase chain reaction (RT-qPCR) was used to evaluate the transcription levels of genes encoding COL-I and OPN proteins. Table 1 shows the sequence of primers.

At $24 \mathrm{~h}, 48 \mathrm{~h}$ and $72 \mathrm{~h}$, the culture medium was removed from the wells (stored at $-80^{\circ} \mathrm{C}$ for secreted protein assays) and the cells were collected for RNA extraction using the Illustra RNASpin Mini Kit (GE Healthcare, Milwaukee, WI, USA), according to the manufacturer's instructions. Samples were quantified by spectrophotometry (NanoVue) and the quality was established at A260/A280> 1.6. The complementary DNA was synthesized using the ThermoScientific cDNA kit, according to the manufacturer's instructions.

The reactions of were performed using the SYBR Green system (Thermo Fisher Scientific, Waltham, MA, USA) on a Real Time PCR System (Applied Biosystems, Foster City, CA, USA).

The results were analyzed based on $\mathrm{Ct}$ (Cycle Threshold), which corresponds to the number of cycles at which the amplification of the samples reached a threshold between the fluorescence level and the amplification phase (determined between the fluorescence level in relation to the negative control, C6). The 2- $\Delta \Delta$ CT method (Livak \& Schmittgen, 2001) was used to determine expression of the target genes.

\section{Total protein assay}

Prior to the protein secretion assays (ELISA), the culture medium was normalized via total protein quantification following the method of Lowry et al. (1951), in a spectrophotometer (CE3021, Cecil, Cambridge, England) at $680 \mathrm{~nm}$. Total protein concentration was calculated for each well in $\mathrm{g} /$ $\mathrm{mL}$ from a standard curve based on bovine serum albumin (Sigma).

Enzyme immunoassay for collagen type I (COL-I) and osteopontin (OPN)

Quantification of COL-I and OPN secreted by the osteoblastic cells under different MLT doses was
Table 1. Sequence of primers for collagen type 1 (COL-I), osteopontin (OPN) and the endogenous control (GAPDH).

\begin{tabular}{|c|c|c|}
\hline Gene name & Gene symbol & Primer Sequence \\
\hline COL- I & COL1A1 & $\begin{array}{l}\text { F 5' CCAGAAGAACTGGTA- } \\
\text { CATCAGCAA-3 R 5' GGACAT- } \\
\text { CAGGCGCAGGAA-3' }\end{array}$ \\
\hline OPN & OPN & $\begin{array}{c}\text { F 5'-TGCTTGGGTTTG- } \\
\text { CAGTCTTCT-3' R 5'-CCAAA- } \\
\text { CAGGCAAAAGCAAATC-3 }\end{array}$ \\
\hline $\begin{array}{l}\text { Glucose } 6 \\
\text { phosphate } \\
\text { dehydroge- } \\
\text { nase }\end{array}$ & GAPDH & $\begin{array}{l}\text { F 5' ACCCACTCCTC- } \\
\text { CACCTTTGA-3' } \\
\text { R 5'-TGTTGCTGTAGC- } \\
\text { CAAATTCGTT-3' }\end{array}$ \\
\hline
\end{tabular}

performed using ELISA (Kit ELISA for COL-I R\&D Systems, EUA; Kit ELISA for OPN CloudClone Corp, Katy, TX, USA).

The reactions were terminated by adding $50 \mu \mathrm{L}$ of $2 \mathrm{~N}$ sulfuric acid $\left(\mathrm{H}_{2} \mathrm{SO}_{4}\right)$ to the substrate solution in each well and the color was measured on a spectrophotometer (Epoch, Biotek, Winooski, VT, USA) at $450 \mathrm{~nm}$. The total amount of COL-I and OPN were determined in picograms per milliliter $(\mathrm{pg} / \mathrm{mL})$. All experiments were performed in triplicate. The primers used are listed in Table 1.

\section{Mineralization assays}

\section{Alizarin red}

Osteoblastic cells, except those from the control group, were cultured with MLT at $0.01,0.1$ and 1 $\mathrm{mM}$ and analyzed at 10 days and 14 days, with the culture medium changed every 2-3 days together with supplementation of MLT. The wells were rinsed and prepared for evaluation under a light microscope (Nikon eclipse E800, Japan). The presence of calcium deposits was identified by the development of red color in the matrix and photographs were taken. The images were processed and later analyzed on Image $\mathrm{J}(\mathrm{NIH})$. The percentage of calcium nodules formed was determined based on optical density from the images taken from each sample.

After 10 days of culture with the different concentrations of MLT, $280 \mu \mathrm{l}$ of $10 \%$ acetic acid was added to each well and the plate was shaken for $30 \mathrm{~min}$. The cell layer was then scraped off and the solution transferred to $1.5 \mathrm{ml}$ tubes, which were vortexed for $30 \mathrm{~s}$. Samples were first heated at $85^{\circ} \mathrm{C}$ for $10 \mathrm{~min}$ and immediately placed in ice for $5 \mathrm{~min}$. Subsequently, the tubes were centrifuged at 
$13,000 \mathrm{~g}$ for $20 \mathrm{~min}$ and $100 \mu \mathrm{l}$ of the supernatant was transferred to a 96-well plate, where $40 \mu \mathrm{l}$ of $10 \%$ ammonium hydroxide was added to each well. The samples were read on a spectrophotometer at $405 \mathrm{~nm}$.

\section{Alkaline phosphatase assay - Fast Red test}

The cultures were treated as per the alizarin red assay until the culture medium was removed and the wells washed with Hanks' solution (Sigma) heated to $37^{\circ} \mathrm{C}$. Three hundred and twenty milligrams of the Triz reagent (Sigma) were dissolved in $20 \mathrm{~mL}$ of deionized water for further addition of $7 \mathrm{mg}$ of the Fast Red Reagent (Sigma). Two mL of this solution were discarded and 8mg Naftol (Sigma) diluted in $2 \mathrm{~mL}$ of dimethyl formamide (Merck), forming the working solution. One $\mathrm{ml}$ of this solution was added to each well and the plate was placed in a moist-air incubator at $37{ }^{\circ} \mathrm{C}$ with $5 \% \mathrm{CO}_{2}$ for $30 \mathrm{~min}$. The solution was then withdrawn and the plate dried for further photographic documentation. The images were processed and analyzed on Image $\mathrm{J}(\mathrm{NIH})$, which determined the percentage of nodules formed as a function of the amount of black areas within the total field.

\section{Statistical analysis}

Data were analyzed using two-way analysis of variance and multiple comparisons were performed using the Tukey test. The analyses were performed on Graphpad Prism version 6.0, considering a significance level of $5 \%$.

\section{RESULTS}

\section{Cell proliferation assay}

Time and concentration factors significantly influenced cell proliferation $(p<0.05)$, with a significant increase in proliferation over time in relation to the control group and at $0.01 \mathrm{mM}$ and $0.1 \mathrm{mM}$ MLT. From analysis of the data at $24 \mathrm{~h}$, no differences were observed between the doses evaluated ( $p>0.05)$. At $48 \mathrm{~h}$ and $72 \mathrm{~h}$, higher mean proliferation values were observed with the lower doses $(0.01,0.1$ and $1 \mathrm{mM})$. Multiple comparisons showed differences, especially at $48 \mathrm{~h}$ and $72 \mathrm{~h}$, in which the higher doses $(2.5$ and $5 \mathrm{mM})$ caused a significant decrease in cell proliferation $(p<0.05)$. This finding guided the exclusion of the doses $2.5 \mathrm{mM}$ and $5 \mathrm{mM}$ from the PCR, ELISA and mineralization assays (Fig.1).

\section{Cell viability assay (MTT)}

The data relating to the MTT assay demonstrated a very similar pattern to that from the proliferation assay in terms of both dose and time, as well as the interaction between the two factors. As shown in Fig. 2, it was observed that at $24 \mathrm{~h}$, the lowest mean cell viability occurred at $5 \mathrm{mM}$ MLT $(\mathrm{p}<0.05)$. At $48 \mathrm{~h}$, the mean cell viability was observed at $5 \mathrm{mM}$, which was significantly lower than for $0.1 \mathrm{mM}$ (p $<0.05)$. At $72 \mathrm{~h}$, both $5 \mathrm{mM}$ and $2.5 \mathrm{mM}$ showed a significantly lower mean cell viability than the remaining groups $(p<0.05)$. At $72 \mathrm{~h}$, the mean viability was significantly higher than at $24 \mathrm{~h}$ at the doses of $0.01,0.1$ and $1 \mathrm{mM}$ and the control. The fact that the higher concentrations $(2.5$ and $5 \mathrm{mM})$ caused a significant decrease in cell viability also led to their exclusion from the subsequent analyses.

\section{Alizarin Red Assay}

At 10 days, as shown in Table 2 and Fig. 3, all doses caused a significant increase $(p<0.05)$ in the formation of mineral nodules when compared to the control group.

The $0.1 \mathrm{mM}$ dose caused the highest quantity of mineral nodules ( $p<0.05$; Fig. 4). The remaining doses did not differ significantly from the control group, with $1 \mathrm{mM}$ showing the lowest quantity of mineral nodules. As shown in Table 2 and Fig. 5, a significant increase in mineral nodules $(p<0.05)$ is observed only for the $0.1 \mathrm{mM}$ group.

\section{Gene expression of COL-I and OPN}

At $24 \mathrm{~h}$, the $1 \mathrm{mM}$ dose significantly up-regulated COL-I gene expression when compared to the remaining groups $(p<0.05)$. For OPN, a significant upregulation occurred with the dose $0.1 \mathrm{mM}(\mathrm{p}<0.05)$.

At $48 \mathrm{~h}$, COL-I expression was significantly upregulated for of 0.1 and $1 \mathrm{mM}(\mathrm{p}<0.05)$, while OPN expression was significantly increased in the 0.01 $\mathrm{mM}$ and $1 \mathrm{mM}$ groups $(\mathrm{p}<0.05)$.

At $72 \mathrm{~h}, \mathrm{COL}-1$ expression was significantly upregulated in $0.1 \mathrm{mM}$ group $(\mathrm{p}<0.05)$ whereas OPN expression peaked at $1 \mathrm{mM}(\mathrm{p}<0.05$, Fig. 6).

For the factor "time", COL-I expression was highest at $72 \mathrm{~h}$ for the doses $0.1 \mathrm{mM}$ and $1 \mathrm{mM}$. This also occurred for OPN expression at $1 \mathrm{mM}(\mathrm{p}<0.05$, Fig. 7).

\section{COL-I and OPN secretion (ELISA)}

The $1 \mathrm{mM}$ dose of MLT significantly increased COL-I secretion when compared to the remaining 


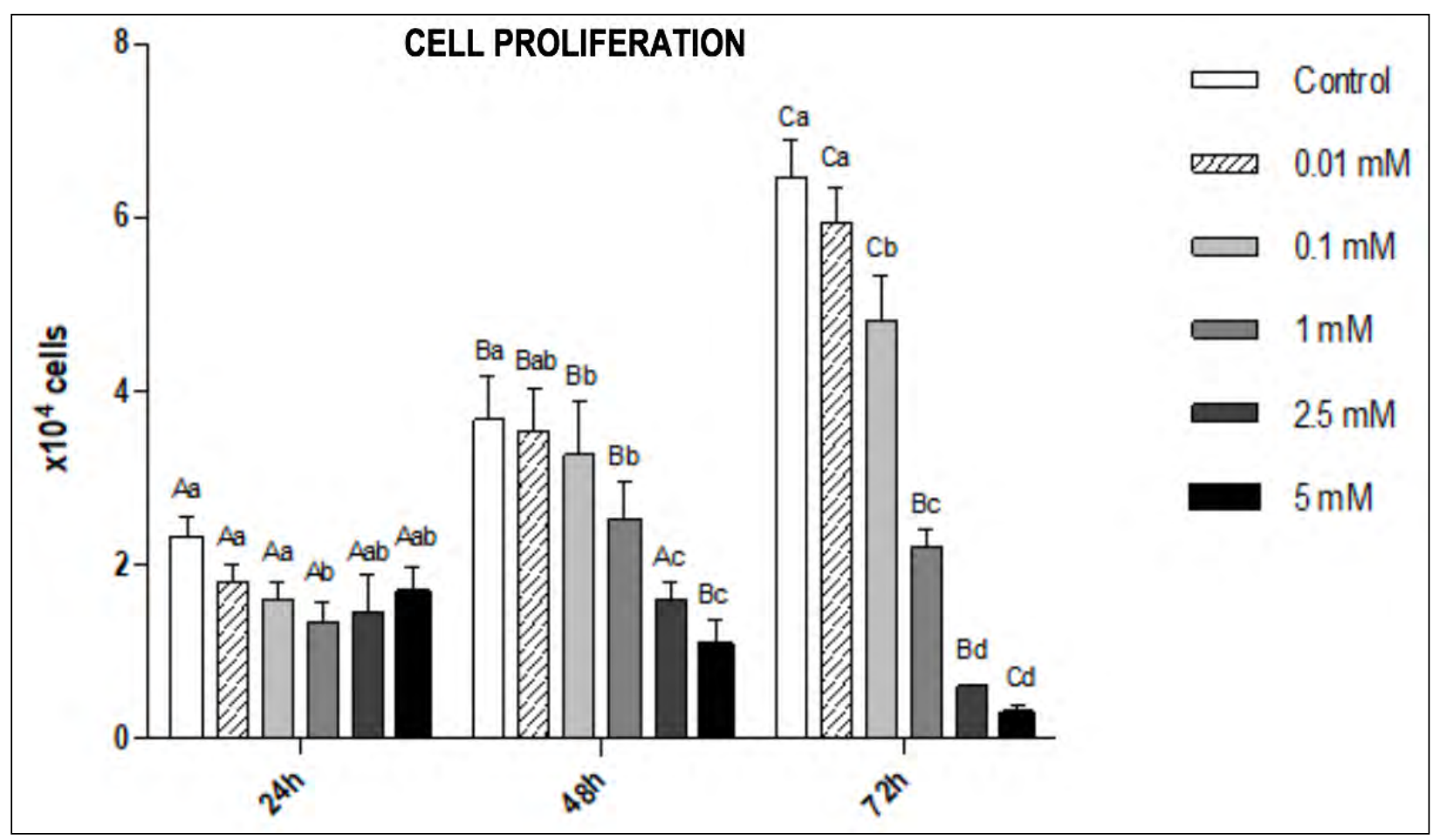

Fig. 1. Evaluation of cell proliferation by the Trypan blue vital exclusion method in pre-osteoblastic cells at 24h, 48h and $72 \mathrm{~h}$, supplemented with MLT at 0.01, 0.1, 1, 2.5 and $5 \mathrm{mM}$, and the control group. Different uppercase letters represent a significant difference between the evaluation periods for each studied condition (ANOVA and Tukey, $\mathrm{p}<0.05$ ); different lowercase letters represent a significant difference between the concentrations tested (ANOVA and Tukey, $\mathrm{p}<0.05$ ).

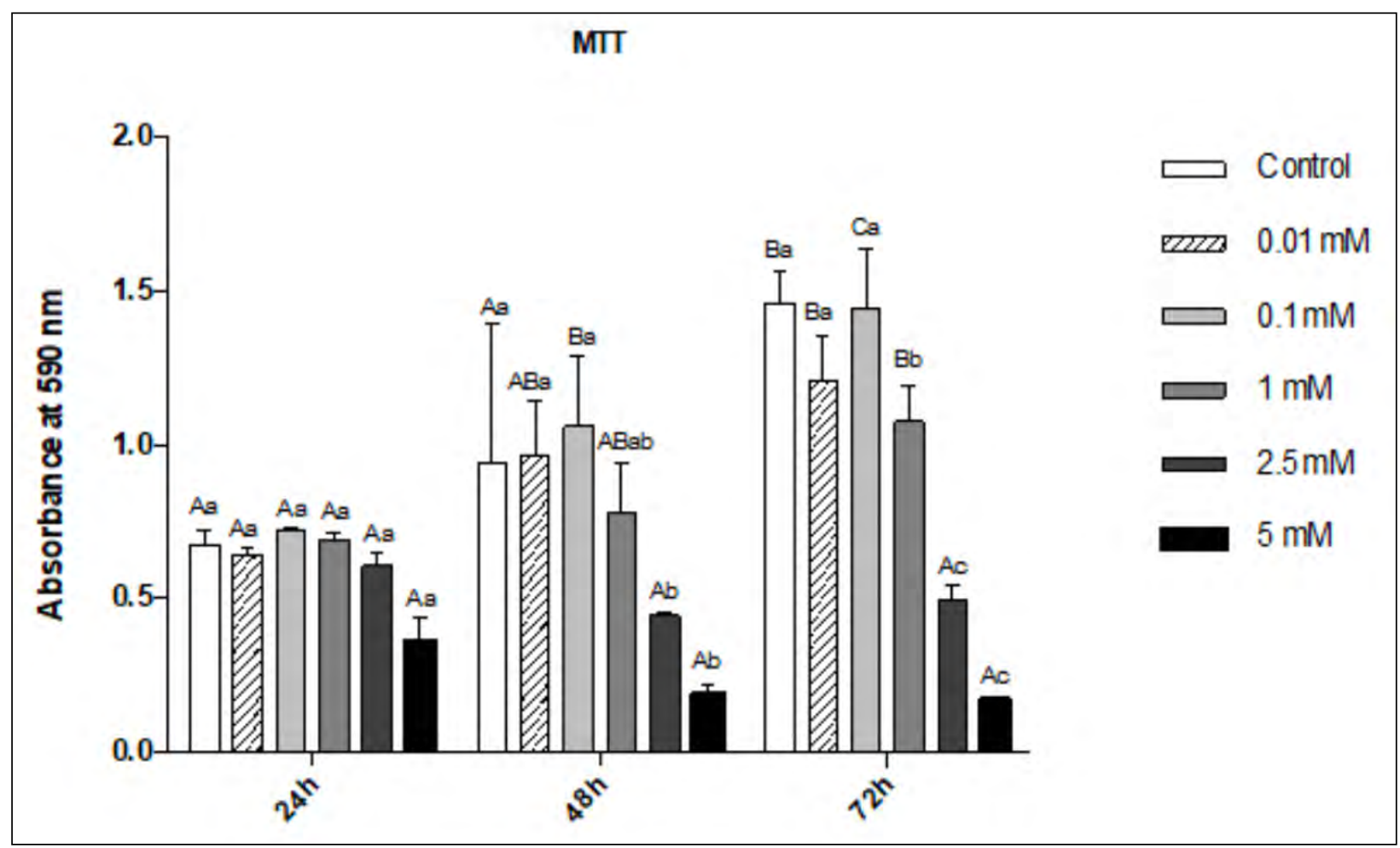

Fig. 2. Cell Viability Assay (MTT) in pre-osteoblastic cells at 24h, 48h and 72h, supplemented with MLT at 5, 2.5, 1, $0.1,0.01 \mathrm{mM}$ and the control group. Different uppercase letters represent a significant difference between the evaluation periods for each studied condition (ANOVA and Tukey, $\mathrm{p}<0.05$ ); different lowercase letters represent a significant difference between the concentrations tested (ANOVA and Tukey, $\mathrm{p}<0.05$ ). 
Table 2. Means (standard deviation) of 10-day mineral nodule counts evaluated using the Alizarin Red (VA) and Fast Red (FR) tests.

CRTL

$0.01 \mathrm{mM}$

$0.1 \mathrm{mM}$

$1 \mathrm{mM}$

VA 15.35 (1.88) A 29.93 (6.03) B 68.24 (3.82) C 45.43 (1.45) D

FR 42.42 (1.93) A 29.43 (5.36) B 66.17 (2.46) C 14.64 (1.31) D

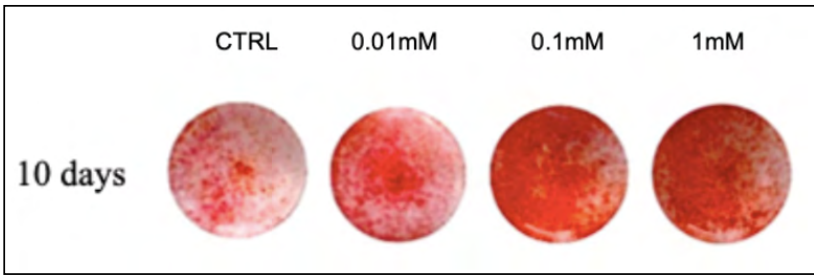

Fig. 3. Representative images from the Alizarin Red test at 10 days, for the different MLT concentrations studied.

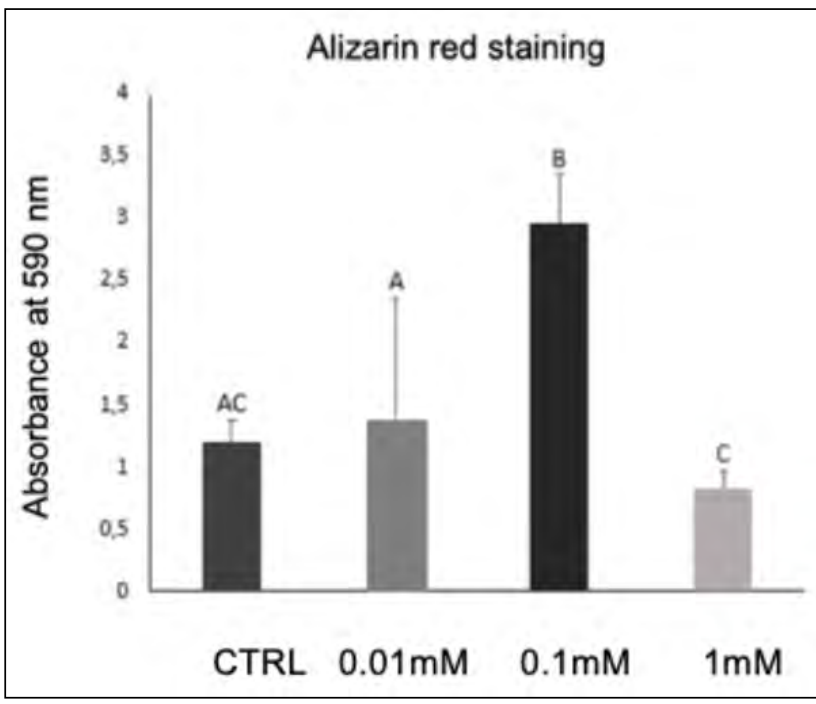

Fig. 4. Mean and standard deviation of Alizarin Red staining for the different MLT concentrations studied at 10 days. Different letters in the columns represent a significant difference between doses (ANOVA and Tukey, $\mathrm{p}<0.05$ ).

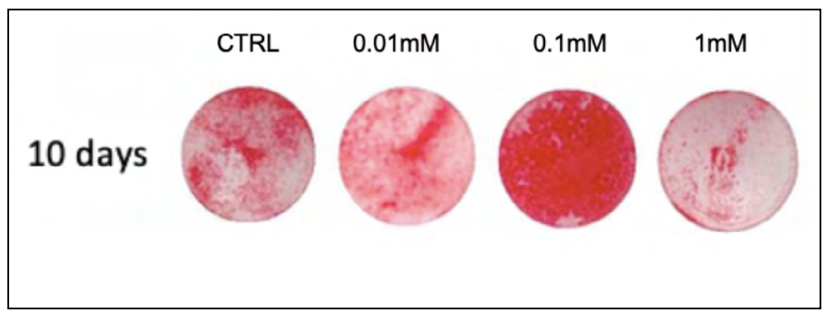

Fig. 5. Representative images of alkaline phosphatase activity for the different MLT doses.

groups at $24 \mathrm{~h}, 48 \mathrm{~h}$ and $72 \mathrm{~h}(\mathrm{p}<0.05$, Fig. 8$)$. A very similar pattern was observed for OPN secretion $(\mathrm{p}<0.05$, Fig.9).

\section{DISCUSSION}

This study investigated the role of MLT in bone metabolism using an in vitro experimental model based on osteoblast cultures for gene expression as well as secretion of key proteins involved in bone physiology, namely COL-I and OPN, over time ${ }^{17,10,12,24,25}$. MLT has been shown to stimulate proliferation and differentiation of human osteoblasts in vitro, as well as the synthesis of COL-I and other proteins of the bone matrix (OPN, OC). Additionally, it has been demonstrated that MLT has the potential to reduce the time of osteoblast differentiation and proliferation ${ }^{9,23,24}$ as a result of the increased expression of bone sialoproteins and enhanced ALP, OPN and osteocalcin activity ${ }^{10,18}$.

It has been demonstrated that the cytoprotective effects of MLT on osteoblasts are noted mainly at low concentrations and shorter times, using concentrations of $1,10,50,100$ and $200 \mathrm{mM}$ for incubation periods of 24,48 and $72 \mathrm{~h}$, showing the cytoprotective effect promoted by MLT in cells treated with bisfosfonate ${ }^{26,27,28,29}$. There is, however, great variability in MLT concentrations across the literature, ranging from 0.001 to $2.5 \mathrm{mM}$ in osteoblastic cells of the MC3T3 lineage ${ }^{9,10,18}$. In the present study, the higher concentrations used, $2.5 \mathrm{mM}$ and $5 \mathrm{mM}$, proved cytotoxic, so they were excluded from the subsequent experiments. The $0.01,0.1$ and $1 \mathrm{mM}$ concentrations were maintained. The time of 21 days is required to allow bone cells to proliferate, differentiate and mineralize in vitro, though considering the potential of melatonin to accelerate this process ${ }^{9}$, the times used in the present investigation were reduced to 10 days. MLT had a substantial effect on COL-I and OPN expression, including decreasing cell differentiation time to 5 7 days ${ }^{15}$, which has guided the design of the present study to evaluate phenotypical features at earlier stages of bone neoformation (10 days as opposed to 14 days). The findings presented herein therefore demonstrate that MLT enhances the process of osteogenesis. This may be attributed to an increase in the expression of bone sialoproteins and alkaline phosphatase activity, activated by the presence of MLT $^{10,24}$. The data obtained in the present study demonstrate that the metabolism of osteoblastic cells was positively affected by the MLT, mainly in relation to the calcium nodule count. On the $10^{\text {th }}$ day, the alizarin red assay showed that all MLT concentrations were able to promote greater 


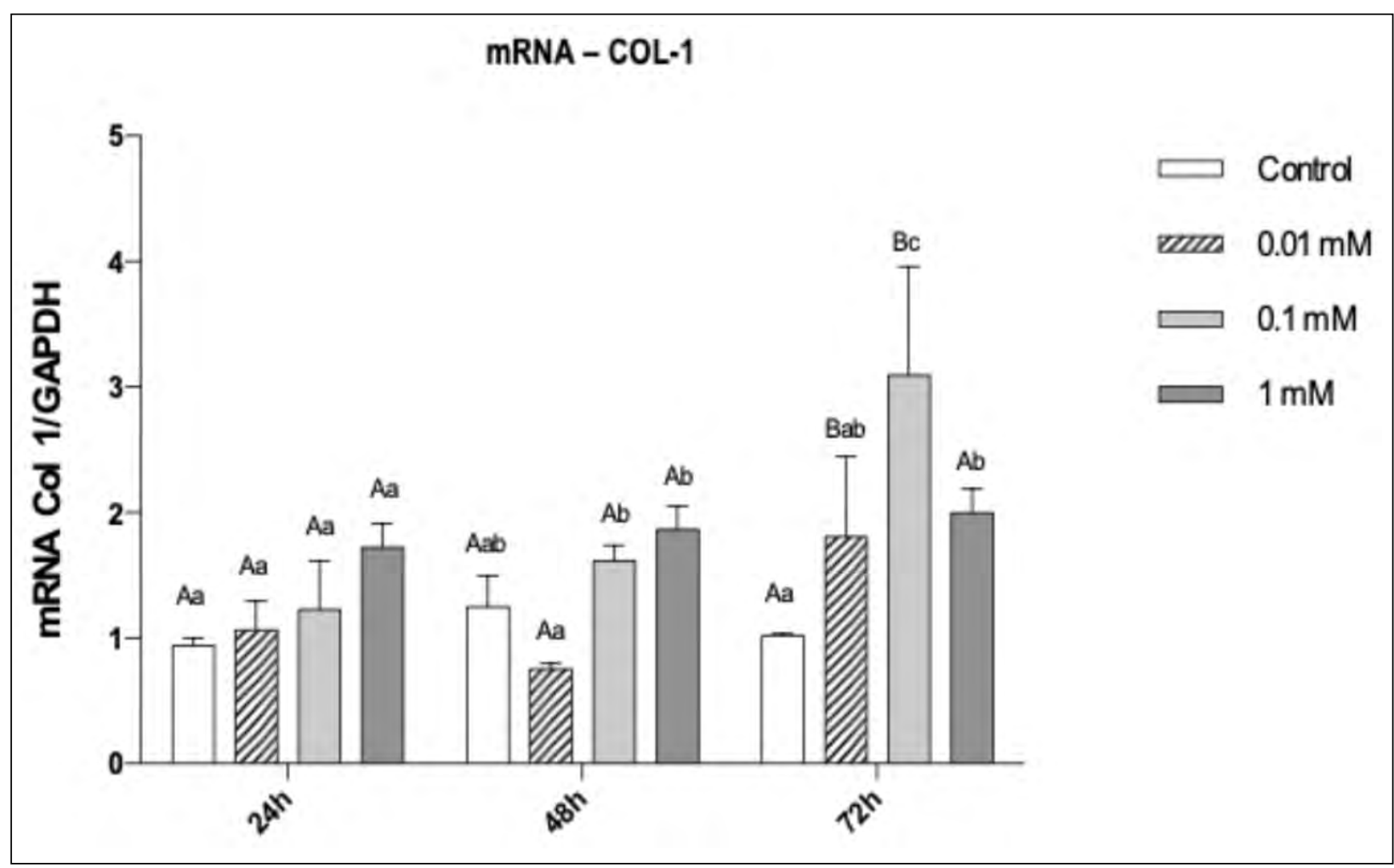

Fig. 6. mRNA expression for COL-1 in pre-osteoblastic cells as a function of MLT dose and time. Different uppercase letters represent a significant difference between the evaluation periods for each studied condition (ANOVA and Tukey, $\mathrm{p}<0.05$ ); different lowercase letters represent a significant difference between the concentrations tested (ANOVA and Tukey, $\mathrm{p}<0.05$ ).

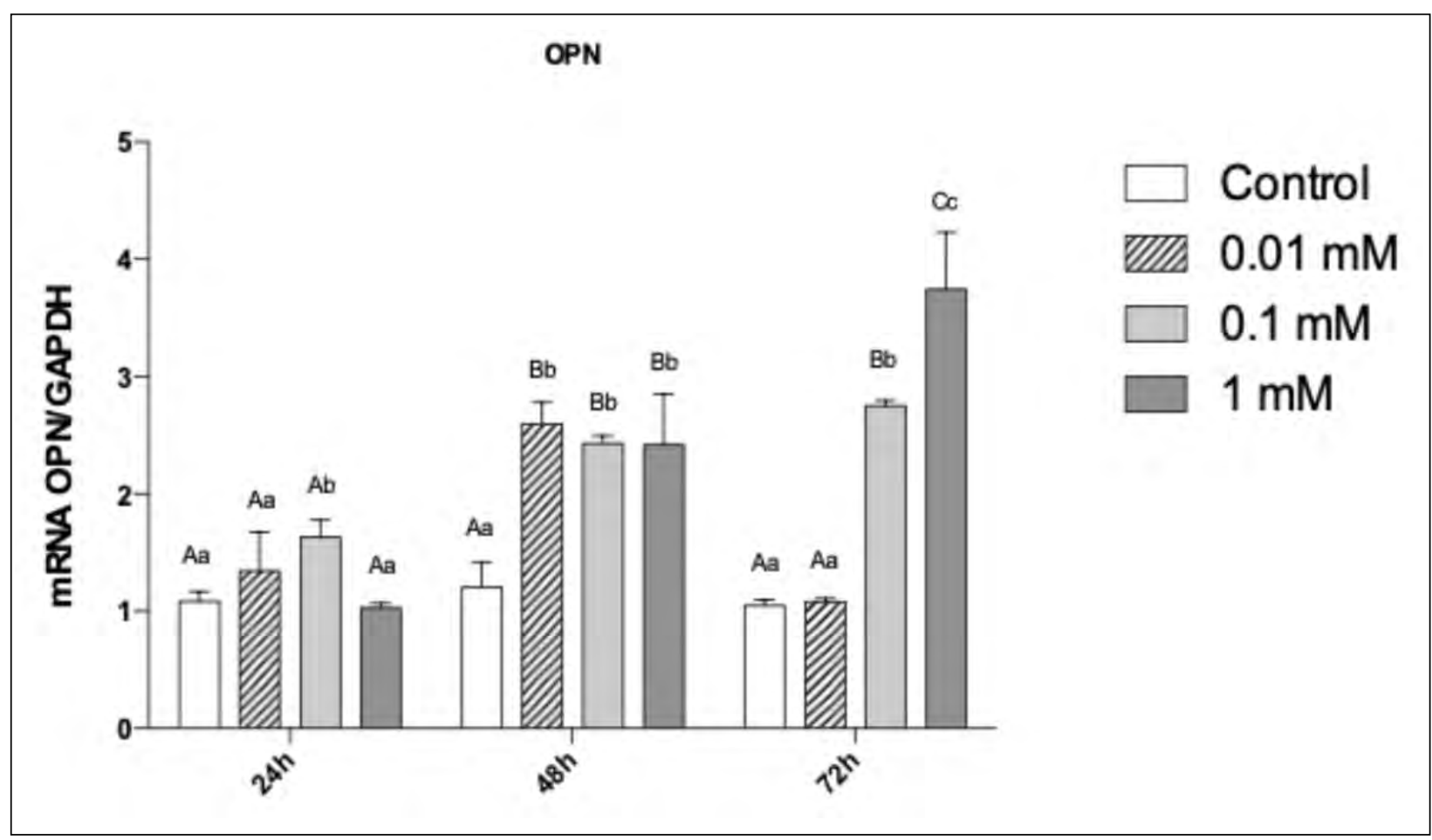

Fig. 7. $m$ RNA expression for OPN in pre osteoblastic cells as a function of MLT dose and time. Different uppercase letters represent a significant difference between the evaluation periods for each studied condition (ANOVA and Tukey, $\mathrm{p}<0.05$ ); different lowercase letters represent a significant difference between the concentrations tested (ANOVA and Tukey, $\mathrm{p}<0.05$ ). 


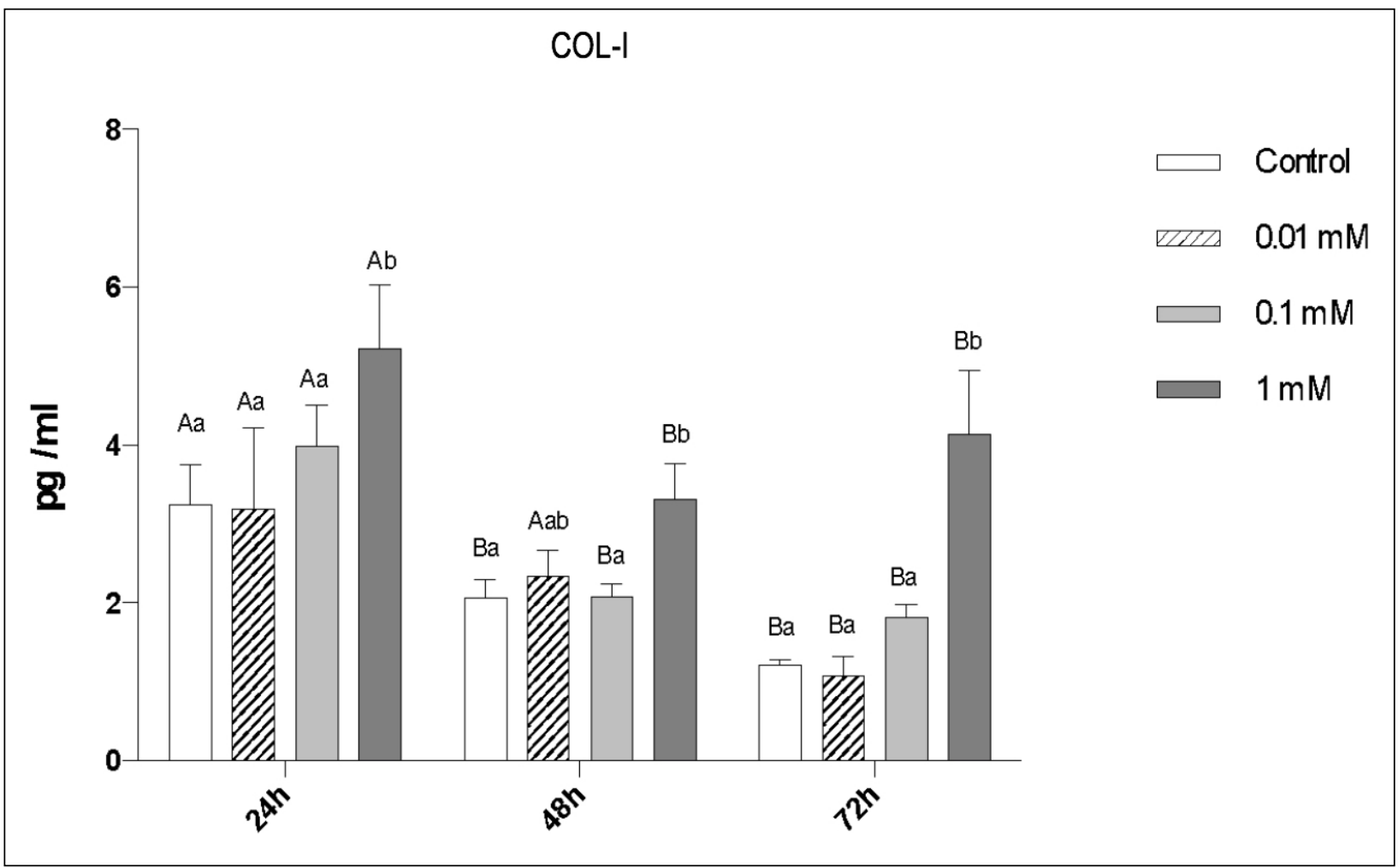

Fig. 8. ELISA for COL-I secretion by pre-osteoblastic cells as a function of MLT dose and time. Different uppercase letters represent a significant difference between the evaluation periods for each studied condition (ANOVA and Tukey, $\mathrm{p}<0.05$ ); different lowercase letters represent a significant difference between the concentrations tested (ANOVA and Tukey, $\mathrm{p}<0.05$ ).

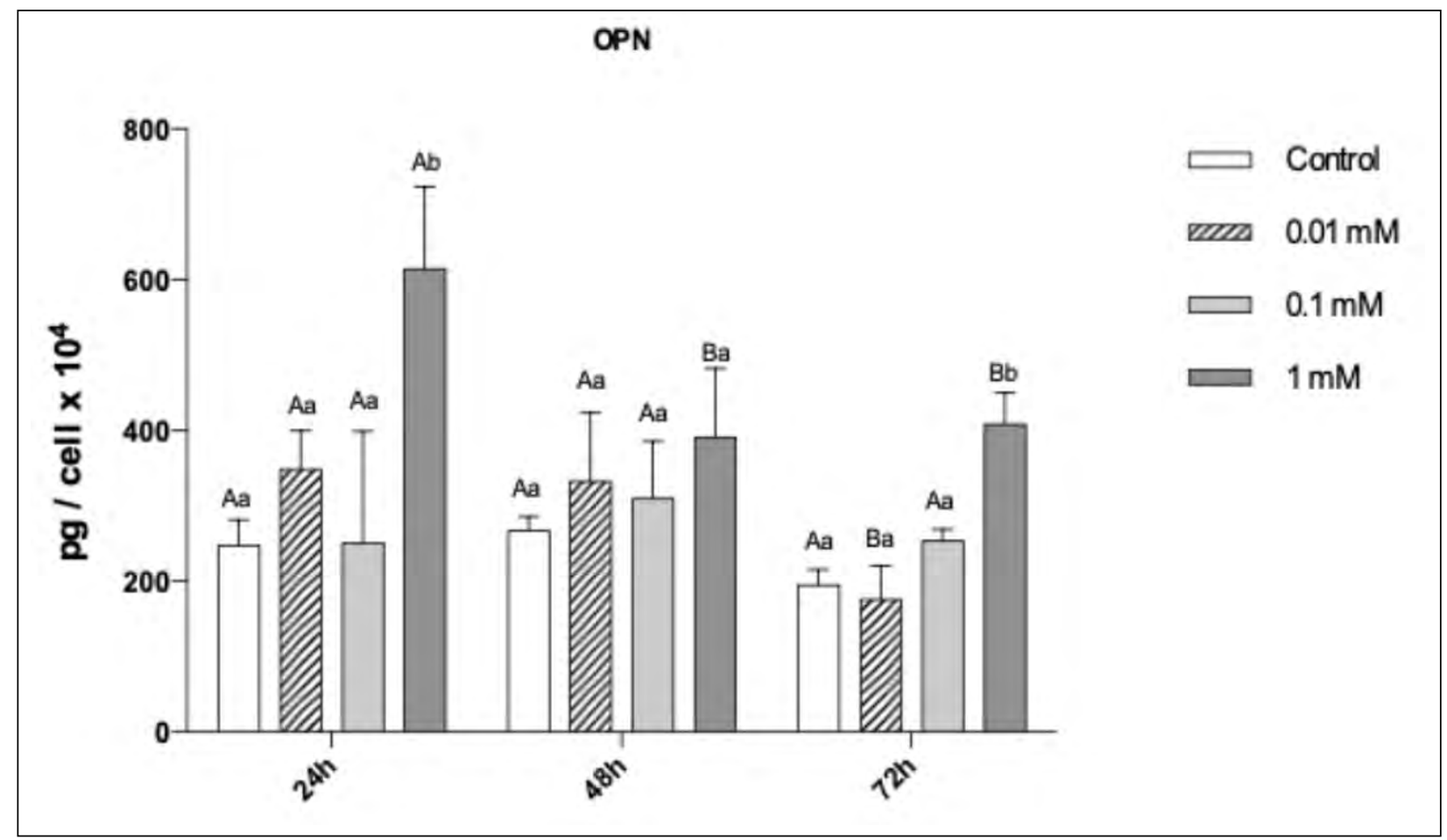

Fig. 9. ELISA for OPN secretion by pre-osteoblastic cells as a function of MLT dose and time. Different uppercase letters represent a significant difference between the evaluation periods for each studied condition (ANOVA and Tukey, $\mathrm{p}<0.05$ ); different lowercase letters represent a significant difference between the concentrations tested (ANOVA and Tukey, $\mathrm{p}<0.05$ ). 
formation of mineral nodules than the control group, especially at the therapeutic dose of $0.1 \mathrm{mM}$. Previous studies ${ }^{10,12,24}$ investigated the direct impact of MLT on pre-osteoblastic cells using increasing doses from $0.001 \mathrm{mM}$ to $2.5 \mathrm{mM}$ to determine its effects on metabolic activity, cell viability and gene expression of markers relating to osteoclastic activation. Subsequently, the best dose $(0.1 \mathrm{mM})$ was applied to assess mineralization, demonstrating that when evaluated using the alizarin red assay at 14 days, a greater formation of mineral nodules was observed in the group treated with MLT, in agreement with the results of the present study.

The alizarin red assay demonstrated the largest quantities of calcium nodules in the presence of $0.1 \mathrm{mM}$ MLT. The higher rate of mineralization in the group treated with melatonin at $0.1 \mathrm{mM}$ may indicate this as most beneficial in an in vitro context. In addition, higher doses can negatively interfere with cell mineralization, demonstrating that there is probably an ideal dose, in which the effect is enhanced, without being cytotoxic ${ }^{10,12,24}$.

In the present study, alkaline phosphatase activity was verified at day 10 and an increase in mineral nodules was observed for the concentration of $0.1 \mathrm{mM} \mathrm{MLT}$, in agreement with studies that suggest that the hormone may have a regulatory effect on bone growth ${ }^{26,27}$. Previous studies ${ }^{13,14,28}$ demonstrated that melatonin was able to regulate osteoblastic function via the MT2 receptor, which showed greater expression in bone during the experiments. In addition, inactivation of this receptor, leaving only MT1 receptor active, negatively affected cell differentiation, proliferation and deposition of the mineralized matrix, thus reiterating the promising role of melatonin as a potential strategy to stimulate bone neoformation.

In an in vivo study performed on a rodent experimental model of induced periodontitis ${ }^{19}$, treatment with MLT reduced serum COL-I

\section{ACKNOWLEDGMENTS}

The authors wish to acknowledge the support and insightful discussions provided by the research and technical staff from Faculdade São Leopoldo Mandic. and increased ALP levels, demonstrating that expression of essential proteins occurred early in the cell differentiation process, as a result of MLT treatment. MLT has an anabolic effect on bone tissue, enhancing mineralization of MC3T3 cells ${ }^{12}$. The MLT-treated cells showed a significant increase in COL-1 and OPN secretion ${ }^{20-22}$. COL-1 and OPN have important roles in organic matrix formation and structural integrity, and are considered key to the mineralization of bone tissue $e^{10,18,19}$. These findings were also observed herein for COL-I expression, which increased at $72 \mathrm{~h}$ at $0.1 \mathrm{mM}$ and $1 \mathrm{mM}$ of MLT, and for OPN expression at $1 \mathrm{mM}$, with concomitant increased ALP at $0.1 \mathrm{mM}$. All such findings are corroborated by studies performed elsewhere ${ }^{12,25}$, though a considerable variation in therapeutic doses is observed across such studies.

The present study has demonstrated a potentially beneficial effect of MLT on MC3T3 cells in the early stages of osteogenesis, both in terms of cell proliferation and viability using doses of $0.01 \mathrm{mM}$ and $0.1 \mathrm{mM}$, respectively, in addition to up-regulating the expression of COL-I and OPN, especially at $72 \mathrm{~h}$ of treatment and doses of $0.1 \mathrm{mM}$ and $1 \mathrm{mM}$, respectively. Increased secretion of COL-I and OPN followed suit at $1 \mathrm{mM}$ and $24 \mathrm{~h}$ of treatment, thus corroborating previous studies on the regulatory effect of melatonin on bone growth ${ }^{10,13,15,21,22,24,25}$. Meanwhile, several important issues remain to be addressed regarding the use of melatonin as a bone augmentation strategy. One of the most important is the lack of consensus regarding the most effective delivery mode, route of administration and dose $\mathrm{e}^{30,25}$. According to the findings in the present in vitro study, MLT at doses ranging from $0.01 \mathrm{mM}$ to 1 $\mathrm{mM}$ had a stimulatory effect on pre-osteoblasts by increasing the synthesis and secretion of both OPN and COL-I, as well as mineralization, thus favoring the process of osteogenesis.

\section{CORRESPONDENCE}

Dr. Karen Dalla Costa.

Rua José Rocha Junqueira, 13, Swift

Campinas, São Paulo, Brasil.

E-mail: kldallacosta@hotmail.com

FUNDING

None. 


\section{REFERENCES}

1. Cutando A, Gomez-Moreno G, Arana C, Acuna-Castroviejo D. Melatonin: potential functions in the oral cavity. J Periodontol 2007, 78: 1094-1102.

2. Liebmann PM, Wölfler A, Schauenstein K. Interaction of the epiphysis and the immune system. Wien Klin Wochenschr 1997,109: 730-736.

3. Guyomarc'h C, Lumineau S, Vivien-Roels B, Richard J, Deregnaucourt $S$. Effect of melatonin supplementation on the sexual development in European quail (Coturnix coturnix). Behav Processes 2001, 53:121-130.

4. Reiter RJ, Tan DX, Manchester LC, Paredes SD, Mayo JC, Sainz RM. Melatonin and reproduction revisited. Biol Reprod 2009, 81: 445-456.

5. Czesnikiewicz-Guzik M, Konturek SJ, Loster B, Wisniewska $\mathrm{G}$, Majewski S. Melatonin and its role in oxidative stress related diseases of oral cavity. J Physiol Pharmacol 2007, 58: 5-19.

6. Permuy M, López-Peña M, González-Cantalapiedra A, Muñoz F. Melatonin: A Review of Its Potential Functions and Effects on Dental Diseases. Int J Mol Sci 2017, 18:865.

7. Hill SM, Blask DE. Effects of the pineal hormone melatonin on the proliferation and morphological characteristics of human breast cancer cells (MCF-7) in culture. Cancer Res 1988, 48: 6121-6126.

8. Roth JA, Kim BG, Lin WL, Cho MI. Melatonin promotes osteoblast differentiation and bone formation. J Biol Chem 1999, 30, 274: 22041-22047.

9. Satué M, Ramis JM, Del Mar Arriero M, Monjo M. A new role for 5- methoxytryptophol on bone cells function in vitro. J Cell Biochem 2015, 116: 551-518.

10. Radio NM, Doctor JS, Witt-Enderby PA. Melatonin enhances alkaline phosphatase activity in differentiating human adult mesenchymal stem cells grown in osteogenic medium via MT2 melatonin receptors and the MEK/ERK (1/2) signaling cascade. J Pineal Res 2006, 40: 332-342.

11. Son JH, Cho YC, Sung IY, Kim IR, Park BS, Kim YD. Melatonin promotes osteoblast differentiation and mineralization of MC3T3-E1 cells under hypoxic conditions through activation of PKD/p38 pathways. J Pineal Res 2014, 57: 385-392.

12. Cutando A, Montero J, Gómez-de Diego R, Ferrera MJ, Lopez-Valverde A. Effect of topical application of melatonin on serum levels of C-reactive protein (CRP), interleukin-6 (IL-6) and tumor necrosis factor-alpha (TNF- $\alpha$ ) in patients with type 1 or type 2 diabetes and periodontal disease. J Clin Exp Dent 2015, 1,7(5), e628-e633. doi: 10.4317/jced.52604.

13. Suzuki N, Somei M, Seki A, Reiter RJ, Hattori A. Novel bromomelatonin derivatives as potentially effective drugs to treat bone diseases. J Pineal Res 2008, 45: 229-234.

14. Najeeb S, Khurshid Z, Zohaib S, Zafar MS. Therapeutic potential of melatonin in oral medicine and periodontology. Kaohsiung J Med Sci 2016, 32: 391-396.

15. Cutando A, López-Valverde A, Gómez-de-Diego R, Arias-Santiago S, de Vicente-Jiménez J. Effect of gingival application of melatonin on alkaline and acid phosphatase, osteopontin and osteocalcin in patients with diabetes and periodontal disease. Med Oral Patol Oral Cir Bucal 2013, 18: e657-663.

16. Almeida EA, Di Mascio P, Harumi T, Spence DW, Moscovitch A, Hardeland R. Measurement of melatonin in body fluids: standards, protocols and procedures. Childs Nerv Syst 2011, 27: 879-891.
17. Dehghan F, Shahrokhi N, Khaksari M, Soltani Z, Asadikorom G, Najafi A, Shahrokhi N. Does the administration of melatonin during post-traumatic brain injury affect cytokine levels? Inflammopharmacology 2018, 26:1017-1023.

18. Arabacı T, Kermen E, Özkanlar S, Köse O et al. Therapeutic Effects of Melatonin on Alveolar Bone Resorption After Experimental Periodontitis in Rats: A Biochemical and Immunohistochemical Study. J Periodontol 2015;86:874-881.

19. Nakade O, Koyama H, Ariji H, Yajima A, Kaku T. Melatonin stimulates proliferation and type I collagen synthesis in human bone cells in vitro. J Pineal Res 1999;27:106-110.

20. Cobo-Vázquez C, Fernández-Tresguerres I, Ortega-Aranegui R, López-Quiles J. Effects of local melatonin application on post-extraction sockets after third molar surgery. A pilot study. Med Oral Patol Oral Cir Bucal 2014; 19:e628-e633.

21. Liu L, Xu Y, Reiter RJ, Pan Y et al. Inhibition of ERK1/2 Signaling Pathway is Involved in Melatonin's Antiproliferative Effect on Human MG-63 Osteosarcoma Cells. Cell Physiol Biochem 2016;39:2297-2307.

22. Carpentieri AR, Peralta Lopez ME, Aguilar J, Solá VM. Melatonin and periodontal tissues: Molecular and clinical perspectives. Pharmacol Res. 2017;125: 224-231.

23. Majidinia M, Reiter RJ, Shakouri SK, et al. The multiple functions of melatonin in regenerative medicine. Ageing Res Rev. 2018;45:33-52.

24. Park KH, Kang JW, Lee EM, Kim JM et al. Melatonin promotes osteoblastic differentiation through the BMP/ERK/ Wnt signaling pathways. J Pineal Res. 2011;51:187-194.

25. Maria S, Samsonraj RM, Munmun F, Glas J et al. Biological effects of melatonin on osteoblast/osteoclast cocultures, bone, and quality of life: Implications of a role for MT2 melatonin receptors, MEK1/2, and MEK5 in melatonin-mediated osteoblastogenesis. J Pineal Res. 2018;64:12465.

26. Chu ZM, Li HB, Sun SX, Jiang YC, Wang B, Dong YF. Melatonin promotes osteoblast differentiation of bone marrow mesenchymal stem cells in aged rats. Eur Rev Med Pharmacol Sci. 2017;21:4446-4456.

27. Sharan K, Lewis K, Furukawa T, Yadav VK. Regulation of bone mass through pineal derived melatonin-MT2 receptor pathway. J Pineal Res. 2017;63: e12423.

28. Camacho-Alonso A, Urrutia-Rodríguez I, Onate-Cabrerizo D, Onate-Sánchez RE, Rodríguez-Lozano FJ. Cytoprotective effects of melatonin on zolendronic acid-treated human osteoblasts. J Craniomaxillofac Surg.2017;45:1251-1257.

29. Calvo-Guirado JL, Ramírez-Fernández MP, Gómez-Moreno G, Maté Sanchez JE et al. Melatonin stimulates the growth of new bone around implants in the tibia of rabbits. J Pineal Res. 2010;49:356-363.

30. Guardia J, Gómez-Moreno G, Ferrera MJ, Cutando A. Evaluation of effects of topic melatonin on implant surface at 5 and 8 weeks in Beagle dogs. Clin Implant Dent Relat Res. 2011;13:262-268.

31. Tresguerres JA, Kireev R, Forman K, Cuesta S, Tresguerres AF, Vara E. Effect of chronic melatonin administration on several physiological parameters from old Wistar rats and SAMP8 mice. Curr Aging Sci. 2012;5:242-253.

32. Arora $\mathrm{H}$, Ivanovski S. Melatonin as a pro-osteogenic agent in oral implantology: a systematic review of histomorphometric outcomes in animals and quality evaluation using ARRIVE guidelines. J Periodontal Res. 2017;52:151-161. 